\title{
Konsentrasi Katalis dan Suhu Optimum pada Reaksi Esterifikasi menggunakan Katalis Zeolit Alam Aktif (ZAH) dalam Pembuatan Biodiesel dari Minyak Jelantah
}

\author{
Dwi Kartika ${ }^{1 *)}$ dan Senny Widyaningsih \\ Prodi Kimia, Jurusan Matematika dan Ilmu Pengetahuan Alam, \\ Fakultas Sains dan Teknik, Universitas Jenderal Soedirman, Purwokerto 53123 \\ Diterima 03-08-2011Ｄisetujui 18-06-2012
}

\begin{abstract}
Transesterification of waste cooking oil into biodiesel using $\mathrm{KOH}$ catalyst with and without esterification process using activated natural zeolite (ZAH) catalyst has been carried out. Activation of the zeolite was done by refluxing with $\mathrm{HCl} 6 \mathrm{M}$ for $30 \mathrm{~min}$, followed calcining and oxydized at $500^{\circ} \mathrm{C}$ for 2 hours, consecutively. The transesterification without esterification process were done using $\mathrm{KOH}$ catalyst $1 \%(\mathrm{w} / \mathrm{w})$ from oil and methanol weight and oil/methanol molar ratio 1:6 at $60^{\circ} \mathrm{C}$. The esterification reaction was also done using ZAH catalyst then continued by transesterification using $\mathrm{KOH}$ catalyst in methanol media. In order to study the effect of ZAH catalyst concentration at constant temperature, the catalysts were varied, i.e. $0,1,2$, and $3 \%(\mathrm{w} / \mathrm{w})$. To investigate the effect of temperature, the experiments were done at various temperature from $30,45,60$, and $70^{\circ} \mathrm{C}$ at constant catalyst concentration. The conversion of biodiesel was determined by ${ }^{1} \mathrm{H}-\mathrm{NMR}$ spectrometer and physical properties of biodiesel were determined using ASTM standard methods. The results showed that the transesterification using $\mathrm{KOH}$ catalyst without esterification produced biodiesel conversion of $53.29 \%$. The optimum condition of biodiesel synthesis via esterification process were reached at $60^{\circ} \mathrm{C}$ and concentration of ZAH catalyst of $2 \%(\mathrm{w} / \mathrm{w})$, that could give biodiesel conversion $=100.00 \%$. The physical properties were conformed with biodiesel ASTM $2003^{\mathrm{b}}$ and Directorate General of Oil and Gas 2006 specification.
\end{abstract}

Keywords: activated natural zeolite, biodiesel, esterification, waste cooking oil

\begin{abstract}
ABSTRAK
Telah dilakukan transesterifikasi minyak jelantah menjadi biodiesel menggunakan katalis KOH dengan dan tanpa esterifikasi berkatalis zeolit alam aktif (ZAH). Aktivasi zeolit melalui proses refluks dengan $\mathrm{HCl} 6 \mathrm{M}$ selama 30 menit, dilanjutkan kalsinasi dan oksidasi pada $500^{\circ} \mathrm{C}$ selama 2 jam. Transesterifikasi tanpa proses esterifikasi menggunakan katalis $\mathrm{KOH}$ $1 \%$ (b/b) dan ratio molar minyak/metanol 1:6 pada $60^{\circ} \mathrm{C}$. Telah dilakukan juga esterifikasi menggunakan katalis ZAH dilanjutkan transesterifikasi dengan katalis $\mathrm{KOH}$ dalam media metanol. Pengaruh konsentrasi katalis ZAH dikaji dengan variasi konsentrasi $0,1,2$, dan $3 \%$ (b/b) pada suhu konstan. Pengaruh suhu dikaji dengan variasi $30,45,60$, dan $75^{\circ} \mathrm{C}$ pada konsentrasi katalis konstan. Konversi biodiesel ditentukan dengan spektrometer ${ }^{1} \mathrm{H}-\mathrm{NMR}$ sedangkan sifat fisik ditentukan dengan metode ASTM. Hasil penelitian menunjukkan bahwa transesterifikasi menggunakan katalis $\mathrm{KOH}$ tanpa proses esterifikasi menghasilkan konversi biodiesel 53,29\%. Kondisi optimum sintesis biodiesel diperoleh melalui proses esterifikasi pada $60^{\circ} \mathrm{C}$ dan konsentrasi katalis ZAH $2 \%$ dengan konversi biodiesel 100\%. Sifat fisik biodiesel yang diperoleh memenuhi spesifikasi ASTM $2003^{\text {b }}$ dan dirjen Migas 2006.
\end{abstract}

Kata Kunci: biodiesel, esterifikasi, minyak jelantah, zeolit alam aktif

\section{PENDAHULUAN}

Berdasarkan data statistik dunia tahun 2009, bahwa cadangan minyak dunia diperkirakan masih 1,333 triliun barrel yang akan habis dalam waktu 45,7 tahun (BP Statistical

*Telp: +6281392052226

Email: abunasywa1@yahoo.com
Review of World Energy 2010). Cadangan minyak bumi yang semakin menipis mendorong eksplorasi bahan bakar alternatif ramah lingkungan. Rudolf Diesel, pada tahun 1900 menciptakan mesin diesel dengan menggunakan bahan bakar minyak nabati (minyak kacang tanah) (Knothe et al. 1997; 
Khan 2002). Penelitian awal masih memerlukan pengembangan lebih lanjut dalam berbagai macam aspek teknis dan ekonomis. American Society for Testing Materials (ASTM) mendefinisikan biodiesel sebagai mono alkil ester asam lemak rantai panjang yang diturunkan dari bahan baku lemak sebagai sumber yang dapat diperbaharui, seperti minyak nabati dan lemak hewani, untuk digunakan dalam mesin diesel (ASTM 2003 ${ }^{\text {b }}$.

Biodiesel umumnya disintesis melalui transesterifikasi dengan menggunakan katalis basa seperti natrium alkoksida, natrium dan kalium hidroksida, atau natrium dan kalium karbonat (Pinto et al. 2005). Kendala yang dihadapi dalam penggunaan biodiesel adalah harganya yang lebih mahal dibandingkan bahan bakar solar. Penggunaan bahan baku yang melimpah dan murah merupakan upaya dalam menekan biaya produksi biodiesel. Minyak jelantah merupakan salah satu bahan baku biodiesel yang melimpah. Minyak jelantah (minyak goreng bekas) mempunyai kandungan asam lemak bebas yang tinggi hingga 5-30\% b/b (Gerpen 2005), $3-40 \%$ b/b (Srivastava \& Prasad 2000). Kadar asam lemak bebas ini akan menimbulkan reaksi penyabunan apabila bereaksi dengan kalium atau natrium hidroksida (Yan et al. 2009; Salimon et al. 2012), sehingga menghambat pembentukan biodiesel. Salah satu metode untuk mengatasinya yaitu melakukan esterifikasi (pra-transesterifikasi) terhadap minyak jelantah untuk mengurangi kadar asam lemak bebas sebelum dilakukan transesterifikasi. Tujuan esterifikasi mengubah asam lemak bebas menjadi alkil ester (biodiesel).

Esterifikasi dapat dilakukan dengan katalis asam seperti $\mathrm{HCl}$ dan $\mathrm{H}_{2} \mathrm{SO}_{4}$ (Pinto et al. 2005), namun dengan pertimbangan kemudahan pemisahan dan ekonomis maka perlu dicari katalis alternatif menggunakan katalis heterogen. Katalis heterogen yang dapat digunakan dalam pembuatan biodiesel seperti clay dan zeolit (Lee et al. 2009). Penelitian terdahulu Kiss et al. (2006) menggunakan tiga tipe zeolit yaitu H-ZSM-5, zeolit Y, dan zeolit beta sebagai katalis untuk esterifikasi asam laurat (dodecanoic acid) dengan 2-etilheksanol dihasilkan konversi lebih tinggi 1-4\% dibandingkan tanpa katalis. Chung dan Park (2009) memanfaatkan zeolit ZSM-5 (HMFI) dan mordenit (HMOR) sebagai katalis esterifikasi untuk mengkonversi asam oleat menjadi biodiesel dengan konversi 80\%. Carmo et al. (2009) menggunakan katalis zeolit Al-MCM-41 mesopori untuk reaksi esterifikasi asam palmitat dengan metanol menghasilkan metil palmitat dengan konversi $79 \%$.
Indonesia memiliki cadangan deposit zeolit alam yang melimpah dengan kandungan utama mordenit dan klinoptilolit dengan kadar bervariasi. Zeolit alam Wonosari memiliki komposisi modernit 70\% (Trisunaryanti et al. 2000), 48\% (Kartika 2008). Zeolit alam ini masih banyak bercampur dengan pengotor (impurities). Zeolit alam pada umumnya memiliki stabilitas termal yang tidak terlalu tinggi, ukuran pori tidak seragam dan aktivitas katalitik rendah sehingga perlu dilakukan modifikasi atau aktivasi. Aktivasi zeolit dapat dilakukan dengan perlakuan asam, yaitu mereaksikan zeolit dengan larutan asam seperti $\mathrm{HCl}, \mathrm{HF}$, dan $\mathrm{NH}_{4} \mathrm{Cl}$ (Khairinal \& Trisunaryant 2000), $\mathrm{HCl}, \mathrm{HNO}_{3}, \mathrm{H}_{2} \mathrm{SO}_{4}$, dan $\mathrm{H}_{3} \mathrm{PO}_{4}$ (Heraldy et al. 2003). Zeolit alam teraktivasi dimungkinkan dapat digunakan sebagai katalis asam dalam reaksi esterifikasi pada pembuatan biodiesel.

Ketersediaan minyak jelantah dan zeolit alam yang melimpah membuat Indonesia berpotensi memproduksi biodiesel dengan biaya produksi ringan. Dalam penelitian ini dilakukan pembuatan biodiesel dengan dua tahap reaksi berbahan baku minyak jelantah dan zeolit alam sebagai sumber katalis asam untuk esterifikasi sebelum dilakukan transesterifikasi dalam media metanol. Esterifikasi dilakukan dengan memvariasikan suhu dan konsentrasi katalis. Penelitian ini bertujuan untuk mengetahui pengaruh suhu dan konsentrasi katalis terhadap konversi biodiesel serta uji mutu terhadap produk yang dihasilkannya.

\section{BAHAN DAN METODE}

Bahan yang digunakan dalam penelitian adalah: zeolit alam (Wonosari) dengan kandungan utama mordenit dan klinoptilolite (Kartika 2008), minyak jelantah (dari rumah makan di Purwokerto), air bebas ion, bahan kimia dari Merck terdiri atas: metanol p.a, asam sulfat p.a., asam klorida (37\%) p.a., $\mathrm{AgNO}_{3} \mathrm{KOH}$ p.a. dan natrium sulfat anhidrat p.a.

Alat-alat yang digunakan dalam penelitian adalah seperangkat alat gelas laboratorium, satu set alat refluks (labu leher tiga kapasitas $500 \mathrm{~mL}$, termometer, pengaduk magnet, pemanas listrik, dan sistem pendingin), desikator, penyaring 100 mesh, mortar dan cawan porselain, oven, stopwatch, timbangan elektrik, alat-alat uji ASTM terdiri atas: ASTM D 1298, ASTM D 445, ASTM D 93, GC-MS (Shimadzu QP-5000), Spektrometer ${ }^{1}$ H NMR 50 MHz (JEOL JNM-MY60) (Laboratorium Kimia Organik FMIPA UGM).

Prosedur Penelitian. Preparasi Zeolit Alam Aktif (ZAH). Sebanyak $200 \mathrm{~g}$ zeolit alam Wonosari digerus sampai 
halus sehingga lolos penyaring 100 mesh kemudian dimasukkan dalam $100 \mathrm{~mL} \mathrm{HCl} 6 \mathrm{M}$ diaduk dengan pengaduk magnet selama 30 menit melalui proses refluks. Hasilnya dicuci hingga netral dengan cara mengalirkan akuades pada penyaring Buchner sampai tidak mengandung ion $\mathrm{Cl}^{-}$. Cara untuk mengetahui bahwa larutan telah bebas ion adalah dengan menguji filtratnya menggunakan larutan $\mathrm{AgNO}_{3}$, sampai tidak terbentuk warna putih keruh. kemudian dikeringkan pada suhu $105-110^{\circ} \mathrm{C}$ selama 3 jam, dikalsinasi pada suhu $500^{\circ} \mathrm{C}$ selama 2 jam, dioksidasi pada suhu $500^{\circ} \mathrm{C}$ selama 2 jam, dan selanjutnya diayak dengan pengayak 100 mesh. Zeolit yang diperoleh selanjutnya dinamakan ZAH (Kartika 2008).

Preparasi Minyak Jelantah. Minyak jelantah dipanaskan pada suhu $100-120^{\circ} \mathrm{C}$ untuk menguapkan air. Kemudian disaring dengan kertas saring untuk memisahkan minyak dengan pengotor padat yang berukuran besar. Lapisan minyak yang cair dipisahkan lagi dengan corong pisah.

\section{Esterifikasi (Pra-Transesterifikasi) dan} Transesterifikasi Minyak Jelantah. Esterifikasi dan transesterifikasi minyak jelantah dilakukan pada labu leher tiga kapasitas $500 \mathrm{~mL}$, yang dilengkapi dengan tempat katalis, pemanas listrik, termometer, pengaduk magnet, dan sistem pendingin. Proses esterifikasi dibuat variabel proses berupa suhu dan konsentrasi katalis. Suhu reaksi dijaga pada 30, 45,60 , dan $70^{\circ} \mathrm{C}$ dengan laju pengadukan $1200 \mathrm{rpm}$. Variasi katalis pada reaksi yaitu ZAH 1, 2, dan 3\% (b/b), sedangkan sebagai pembanding dilakukan tanpa esterifikasi, menggunakan katalis zeolit alam, dan asam sulfat. Rasio molar minyak-metanol adalah 1:9 dan waktu reaksi 60 menit. Setelah proses, bagian cair dipisahkan dari padatannya dan bagian cair disentrifuge untuk memisahkan pengotor berupa padatan terlarut. Kemudian disaring dan dilakukan distilasi terhadap ekstrak yang diperoleh untuk menguapkan dan menghilangkan adanya air dan metanol yang berlebih (modifikasi) (Kartika 2008).

Prosedur berikutnya transesterifikasi sesuai prosedur (Yoeswono et al. 2007) dengan beberapa modifikasi. Transesterifikasi menggunakan katalis basa $\mathrm{KOH}$ dengan rasio molar minyak-metanol 1:6. Sebanyak $150 \mathrm{~g}$ minyak dimasukkan dalam labu leher tiga, kemudian dirangkai dengan sistem pendingin. Sejumlah 33,49 g metanol dan $1 \%$ (b/b) KOH yang telah dihomogenkan dituang ke dalam labu leher tiga tersebut, dan pengaduk magnet dihidupkan.
Waktu reaksi dicatat sejak pengaduk magnet dihidupkan. Setelah reaksi berjalan 60 menit, pengadukan dihentikan, campuran dituang dalam corong pemisah, dibiarkan terjadi pemisahan selama 2 jam pada suhu kamar. Lapisan metil ester dipisahkan dari lapisan gliserol, selanjutnya sisa metanol dalam lapisan metil ester diuapkan. Sisa katalis dan gliserol dalam metil ester dihilangkan dengan pencucian air berulang kali, sampai diperoleh lapisan air yang jernih. Metil ester dikeringkan dengan penambahan $\mathrm{Na}_{2} \mathrm{SO}_{4}$ anhidrat.

Sebelum dan setelah dilakukan transesterifikasi, minyak dianalisis dengan spektrometer ${ }^{1} \mathrm{H}-\mathrm{NMR}$. Karakter fisik minyak jelantah dan biodiesel yang diperoleh dianalisis meliputi kerapatan spesifik 60/60 ${ }^{\circ} \mathrm{F}$ (ASTM D 1298), viskositas kinematis $40^{\circ} \mathrm{C}$ (ASTM D 445) dan ASTM D 93 untuk titik nyala.

Analisis Konversi Biodiesel dengan ${ }^{1}$ H-NMR. Puncak-puncak dalam spektrometer ${ }^{1} \mathrm{H}-\mathrm{NMR}$ digunakan sebagai acuan dalam menentukan konversi biodiesel, karena puncak pada pergeseran kimia 4,2 ppm adalah khas untuk trigliserida yang tidak dimiliki oleh metil ester. Demikian pula puncak pada pergeseran kimia 3,7 ppm adalah puncak khas untuk metil ester yang tidak dimiliki oleh trigliserida. Keberadaan kedua puncak tersebut dalam spektrum ${ }^{1} \mathrm{H}-\mathrm{NMR}$ produk biodiesel mengindikasikan kurang sempurnanya proses transesterifikasi yang dilakukan. Jadi ada reaktan yang tidak terkonversi menjadi biodiesel (Yoeswono et al. 2007).

Konversi metil ester (\%) dihitung menggunakan Persamaan 1. Faktor 5 dan 9 adalah jumlah proton yang terdapat pada gliseril dalam molekul trigliserida mempunyai 5 proton dan tiga molekul metil ester yang dihasilkan dari satu molekul trigliserida (TG) mempunyai 9 proton (Knothe 2000; Yoeswono et al. 2007).

$$
\mathrm{C}_{\mathrm{ME}}, \%=100 \mathrm{X} \frac{5 \mathrm{I}_{\mathrm{ME}}}{5 \mathrm{I}_{\mathrm{ME}}+9 \mathrm{I}_{\mathrm{TG}}}
$$

Keterangan:

$\mathrm{C}_{\mathrm{ME}}=$ konversi metil ester (\%),

$\mathrm{I}_{\mathrm{ME}}=$ nilai integrasi puncak metil ester (\%),

$\mathrm{I}_{\mathrm{TG}}=$ nilai integrasi puncak trigliserida $(\%)$,

5 = jumlah proton yang terdapat pada gliseril dalam molekul trigliserida mempunyai 5 proton,

9 = tiga molekul metil ester yang dihasilkan dari satu molekul trigliserida (TG) mempunyai 9 proton. 
HASIL DAN PEMBAHASAN

Esterifikasi dan Transesterifikasi. Reaksi esterifikasi merupakan perlakuan awal pada minyak jelantah sebagai usaha untuk menurunkan kandungan asam lemak bebas dalam minyak jelantah. Kadar asam lemak bebas minyak jelantah yang digunakan mencapai $21,4 \%$. Dengan semakin kecilnya kadar asam lemak bebas, maka sabun yang terbentuk semakin sedikit dan hasil metil ester yang diperoleh semakin besar atau dengan kata lain trigliserida sisa yang tidak terkonversi semakin kecil. Analisis untuk menentukan konversi biodiesel dilakukan dengan ${ }^{1} \mathrm{H}-\mathrm{NMR}$. Berikut merupakan kromatogram ${ }^{1} \mathrm{H}-\mathrm{NMR}$ antara minyak jelantah, biodiesel hasil transesterifikasi secara langsung menggunakan $\mathrm{KOH}$ dan biodiesel yang diproduksi melalui perlakuan esterifikasi terlebih dahulu dengan katalis ZAH dan $\mathrm{H}_{2} \mathrm{SO}_{4}$ (Gambar 1). Gambar 1 menunjukkan bahwa perlakuan pra-transesterifikasi (esterifikasi) mempunyai pengaruh yang signifikan terhadap konversi biodiesel. Keadaan ini dapat terjadi karena proses esterifikasi dengan
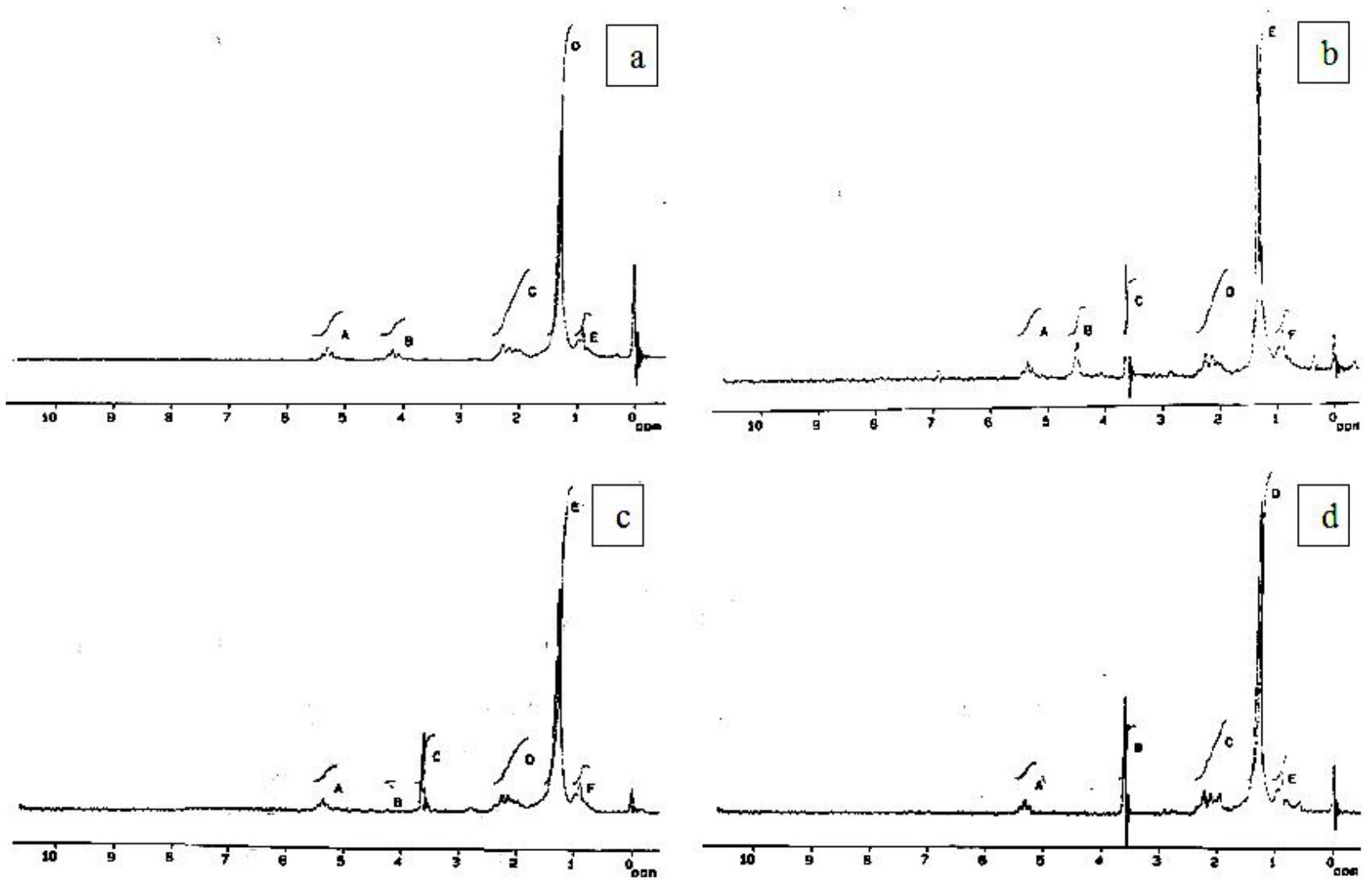

Gambar 1 Spektrum 'H-NMR, a) minyak jelantah; b) biodiesel tanpa perlakuan esterifikasi $(53,29 \%)$; c) biodiesel melalui esterifikasi dengan katalis $\mathrm{H}_{2} \mathrm{SO}_{4}$ (konversi 95,84\%); d) biodiesel melalui esterifikasi dengan katalis $\mathrm{ZAH}$ (konversi $100 \%$ )

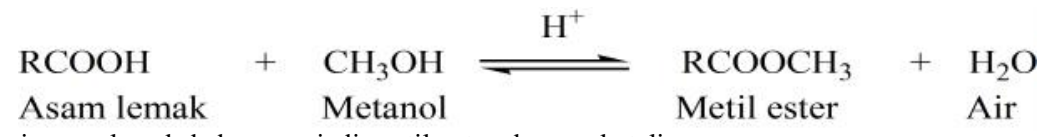

Gambar 2 Reaksi esterifikasi asam lemak bebas menjadi metil ester dengan katalis asam

ZAH mengubah asam lemak bebas menjadi metil ester sehingga meminimalkan reaksi penyabunan dan setelah proses transesterifikasi menghasilkan produk biodiesel dengan jumlah maksimal. Perbedaan konversi biodiesel dengan dan tanpa perlakuan esterifikasi menggunakan katalis ZAH dapat mencapai 46,71\%. Pembuatan biodiesel melalui dua tahap reaksi yaitu reaksi esterifikasi dan transesterifikasi dengan katalis ZAH sebanyak 2\% dapat mencapai konversi $100 \%$ pada suhu $60^{\circ} \mathrm{C}$. Hasil ini lebih baik jika dibandingkan yang diperoleh Lou et al. (2008) dan Yan et al. (2009). Lou et al. (2008), melaporkan zirkonia sulfat dan asam niobat dapat digunakan sebagai katalis esterifikasi dan transesterifikasi minyak jelantah yang memiliki kadar asam lemak bebas $27,8 \%$ (b/b) dengan konversi 44 dan $16 \%$. Yan et al. (2009), menggunakan katalis $\mathrm{ZnO}-\mathrm{La}_{2} \mathrm{O}_{3}$ untuk reaksi esterifikasi dan transesterifikasi secara simultan pada minyak jelantah selama 3 jam diperoleh konversi $96 \%$. Secara teori reaksi dalam pembuatan biodiesel melalui 2 tahap reaksi ditunjukkan dalam Gambar 2 dan 3. 
Komposisi asam lemak yang terkandung dalam biodiesel dianalisis dengan kromatografi gas-spektroskopi massa pada konversi tertinggi yang diperoleh dari analisis ${ }^{1} \mathrm{H}-\mathrm{NMR}$. Berdasarkan data fragmentasi diperoleh komposisi asam lemak (Tabel 1). Tabel 1 menunjukkan bahwa komposisi asam lemak terbesar yaitu asam oleat (C18:1) 46,53\%; asam palmitat (C16:0) 17,98\% dan asam lenoleat (C18:2) 10,21\%. Asam oleat merupakan komponen terbesar sesuai dengan Chhetri et al. (2008) dan Issariyakul et al. (2007), sedangkan urutan kedua dan ketiga berbeda dengan kedua penelitian tersebut. Perbedaan komposisi asam lemak dimungkinkan dari perbedaan sumber atau asal minyak jelantah yang digunakan.

Pengaruh Suhu terhadap Konversi Biodiesel. Penelitian ini mempelajari variabel pada reaksi esterifikasi dengan katalis ZAH dan membuat perlakuan sama terhadap reaksi transesterifikasi. Berdasarkan Gambar 4 terlihat bahwa suhu optimum diperoleh pada $60^{\circ} \mathrm{C}$. Pada suhu rendah $\left(30^{\circ} \mathrm{C}\right)$ konversinya paling rendah, karena secara umum kenaikan suhu akan menyebabkan gerakan molekul semakin cepat (tumbukan antara molekul reaktan meningkat) atau energi kinetik yang dimiliki molekul reaktan semakin besar sehingga terdapat lebih banyak molekul dapat mengatasi energi aktivasi atau dengan kata lain peningkatan suhu akan meningkatkan probabilitas molekul dengan energi yang sama atau lebih tinggi dari energi aktivasi (Pachenkov \& Lebedev 1976). Keadaan ini menyebabkan kecepatan reaksi semakin meningkat sehingga konversinya meningkat.

Suhu optimum dicapai pada $60^{\circ} \mathrm{C}$ dengan konversi $100 \%$, pada suhu tersebut mendekati titik didih metanol sehingga dimungkinkan intensitas tumbukan antar reaktan meningkat dan mencapai titik optimum. Suhu optimum tersebut mendekati suhu optimum yang diperoleh beberapa penelitian terdahulu dengan katalis yang berbeda. Chung \& Park (2009) melaporkan suhu optimum esterifikasi asam oleat menjadi biodiesel dengan katalis zeolit ZSM-5 (HMFI) dan mordenit (HMOR) diperoleh pada suhu $60^{\circ} \mathrm{C}$ dengan konversi 80\%. Feng et al. dalam Sharma et al. (2011) melaporkan pembuatan biodiesel dari minyak jelantah menggunakan resin penukar kation (NKC-9) diperoleh konversi optimal sebesar $90 \%$ pada suhu $64^{\circ} \mathrm{C}$. Pada suhu $70^{\circ} \mathrm{C}$ konversinya menurun yang disebabkan pada suhu $70^{\circ} \mathrm{C}$ melebihi titik didih metanol, akibatnya sebagian metanol mengalami perubahan fasa dari cair menjadi gas sehingga jumlah metanol dalam fasa cair berkurang. Kondisi ini dapat menyebabkan berkurangnya tumbukan antara molekul reaktan sehingga kecepatan reaksi menurun dan pada akhirnya konversi biodiesel juga turun.

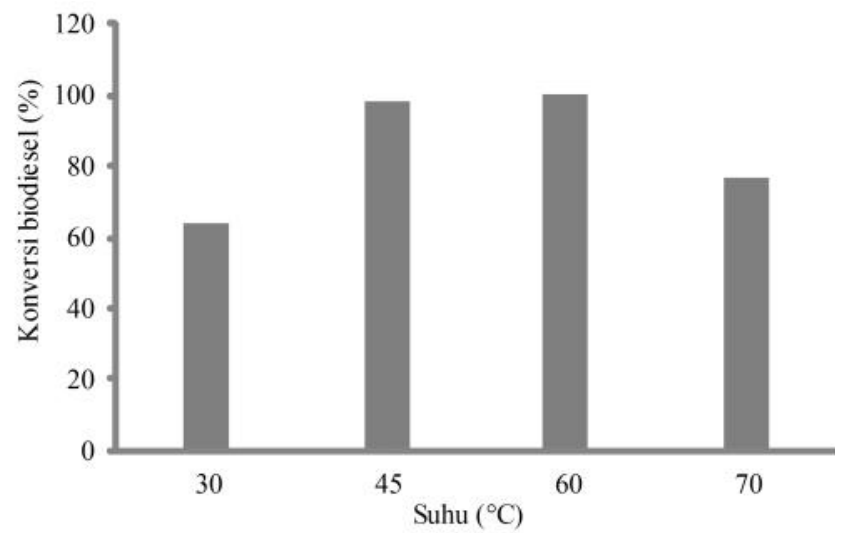

Gambar 4 Pengaruh suhu terhadap konversi biodiesel

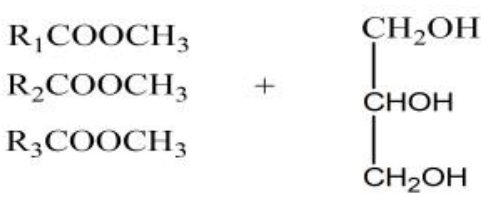

Metil ester

Gliserol

Trigliserida

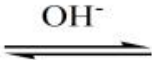

Gambar 3 Reaksi transesterifikasi trigliserida menjadi metil ester dengan katalis basa; $R_{1}, R_{2}, R_{3}$ merupakan asam lemak jenuh dan tidak jenuh

Tabel 1 Komposisi asam lemak yang terkandung dalam sampel biodiesel

\begin{tabular}{|c|c|c|c|c|}
\hline \multirow{2}{*}{ Nama senyawa } & \multicolumn{4}{|c|}{ Kadar } \\
\hline & Struktur & Biodiesel $^{\text {a) }}$ & Biodiesel $^{\text {b) }}$ & Biodiesel $^{\mathrm{c})}$ \\
\hline Asam miristat & C14:0 & 0,76 & 0,11 & 0,41 \\
\hline Asam palmitat & $\mathrm{C} 16: 0$ & 17,98 & 5,18 & 8,22 \\
\hline Asam palmitoleat & C16:1 & 0,25 & 0,51 & 0,89 \\
\hline Asam stearat & C18:0 & 4,09 & 2,1 & 5,61 \\
\hline Asam oleat & C18:1 & 46,53 & 59,7 & 48,83 \\
\hline Asam linoleat & C18:2 & 10,21 & 19,31 & 10,94 \\
\hline Asam linolenat & C18:3 & 3,8 & 6,82 & 2,68 \\
\hline
\end{tabular}

a) Biodiesel hasil eksperimen; b) Chhetri et al. 2008; c) Issariyakul et al. 2007 
Pengaruh Konsentrasi Katalis terhadap Konversi

Biodiesel. Berdasarkan penelitian diperoleh data yang menunjukkan bahwa pembuatan biodiesel dari minyak jelantah tanpa proses esterifikasi, konversi biodiesel yang diperoleh paling kecil yakni 53,29\%. Pembuatan biodiesel melalui tahap esterifikasi menggunakan zeolit alam tanpa diaktivasi sebagai katalis dihasilkan konversi tidak jauh beda dengan tanpa esterifikasi sebesar 55,94\%. Fakta ini dimungkinkan zeolit alam yang belum diaktivasi luas permukaannya kecil karena pori-porinya masih tertutup oleh mineral-mineral maupun senyawa organik. Oleh karena itu zeolit tersebut aktivitasnya katalitiknya menjadi rendah. Proses dengan katalis asam sulfat diperoleh konversi biodiesel 95,84\%, nilai konversi ini lebih baik dibandingkan tanpa perlakuan esterifikasi. Asam sulfat merupakan katalis asam homogen yang umum dipakai dalam reaksi esterifikasi (Sharma et al. 2011; Yan et al. 2009). Yan et al. (2009) melaporkan konversi biodiesel dengan katalis asam sulfat sebesar 88-97\%. Pemakaian katalis zeolit alam aktif (ZAH) $1 \%$ didapatkan konversi biodiesel 96,7\%. Perlakuan dengan katalis ZAH 2\% didapatkan konversi biodiesel $100 \%$.

Zeolit alam teraktivasi $\mathrm{HCl}(\mathrm{ZAH})$ merupakan katalis asam yang sudah dicuci sehingga tidak mengandung ion $\mathrm{Cl}^{-}$terbukti tidak munculnya endapan putih sewaktu ditetesi dengan $\mathrm{AgNO}_{3}$. Pada dasarnya katalis ZAH merupakan zeolit alam yang diaktivasi dengan $\mathrm{HCl} 6 \mathrm{M}$ telah mengalami dealuminasi sehingga rasio $\mathrm{Si} / \mathrm{Al}$ dalam kristal zeolit meningkat diiringi pula dengan kenaikan keasamannya (Rabo et al. dalam Rebeiro 1984) dengan demikian sifat katalis ZAH adalah asam. Dengan semakin besar jumlah konsentrasi katalis ZAH diharapkan akan meningkatkan laju reaksi pada pembuatan biodiesel. Kenaikan konsentrasi katalis tidak menyebabkan pergeseran kesetimbangan ke arah pembentukan metil ester, tetapi menyebabkan turunnya energi aktivasi. Dengan demikian akan meningkatkan kualitas tumbukan antar molekul reaktan yang mengakibatkan kecepatan reaksi esterifikasi menjadi naik maka konversi metil ester juga menjadi semakin tinggi. Pemakaian katalis untuk pembuatan biodiesel agar diperoleh konversi maksimal diperlukan konsentrasi katalis yang berbeda-beda bergantung pada jenis katalis dan kondisi reaksinya. Konsentrasi katalis optimum dalam pembuatan biodiesel yang telah dilaporkan yaitu katalis resin gelular EBD $1001 \% \mathrm{~b} / \mathrm{b}$, zirconia sulfat $3 \% \mathrm{~b} / \mathrm{b}$, silika $1,5 \% \mathrm{~b} / \mathrm{b}$, dan zeolit H-ZSM- 5 (HMFI) 0,06 mmol/g (Sharma et al. 2011).

Penggunaan katalis ZAH 3\% terjadi penurunan konversi menjadi 98,41\% (Gambar 5). Hal ini diperkirakan karena terjadinya kompetisi dari metanol dalam reaksi esterifikasi sebagai reaktan dan sebagai pelarut. Selain berperan sebagai reaktan, metanol juga berperan sebagai pelarut protik yang dapat menyeimbangkan anion yang terbentuk dari katalis setelah melepaskan proton (dari situs asam Brønsted katalis). Pada penggunaan katalis sebanyak 3\%, semakin banyaknya anion yang terbentuk setelah situs asam Brønsted dari katalis melepaskan proton untuk proses katalitik. Akibatnya semakin banyak pula metanol yang dibutuhkan untuk menyeimbangkan anion dari katalis tersebut. Hal ini mengakibatkan metanol yang terlibat dalam reaksi akan berkurang dari seharusnya, sehingga reaksi esterifikasi menjadi tidak optimal dan asam lemak bebas yang ada dalam minyak jelantah tidak seluruhnya teresterkan. Adanya asam lemak bebas akan mengganggu dalam reaksi

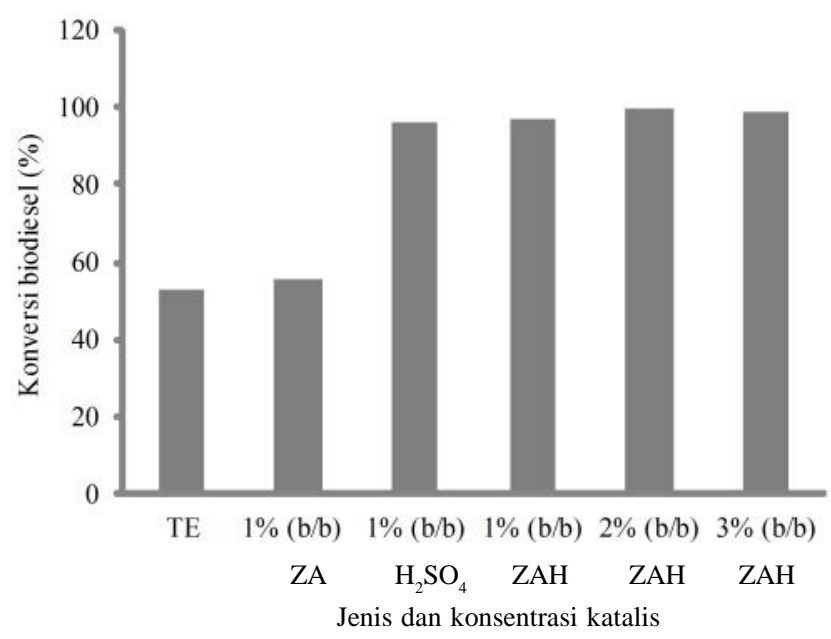

Gambar 5 Pengaruh konsentrasi katalis terhadap konversi biodiesel, TE (tanpa esterifikasi); ZA (zeolit alam); $\mathrm{H}_{2} \mathrm{SO}_{4}$ (asam sulfat); $\mathrm{ZAH}$ (zeolit teraktivasi $\mathrm{HCl}$ )

Tabel 2 Sifat fisik biodiesel

\begin{tabular}{|c|c|c|c|c|c|c|}
\hline \multirow{2}{*}{ Parameter } & \multicolumn{2}{|c|}{ Hasil uji } & \multicolumn{2}{|c|}{ Batasan biodiesel*) } & \multicolumn{2}{|c|}{ Batasan minyak solar $48 * *)$} \\
\hline & Minyak jelantah & Biodiesel & $\min$ & maks & Min & Maks \\
\hline Berat jenis pada $60 / 60^{\circ} \mathrm{F}$, g.cm ${ }^{3}$ & 0,91 & 0,87 & - & - & 0,82 & 0,87 \\
\hline Viskositas kinematik pada $40^{\circ} \mathrm{C}, \mathrm{cSt}$ & 39,07 & 3,06 & 1,90 & 6,00 & 2,00 & 5,00 \\
\hline Titik nyala, $\mathrm{cc},{ }^{\circ} \mathrm{C}$ & 248,00 & 142,00 & 130,00 & - & 60,00 & - \\
\hline Kadar gliserol, \% (b/b) & 0,00 & - & - & 0,24 & - & - \\
\hline
\end{tabular}

Sumber: *) ASTM 2003 ${ }^{\text {}}$;**) Dirjen Migas (2006) 
transesterifikasi sehingga mengakibatkan konversi biodiesel yang dihasilkan menjadi berkurang.

Analisis Kualitas Biodiesel. Analisis kualitas biodiesel meliputi ASTM D 1298 untuk berat jenis, ASTM D 445 untuk viskositas kinematis, ASTM D 93 untuk titik nyala, ${ }^{1} \mathrm{H}-\mathrm{NMR}$ untuk gliserol total (Tabel 2). Trigliserida mempunyai densitas yang lebih tinggi dari metil ester (biodiesel). Masih adanya trigliserida dalam biodiesel merupakan akibat dari kurang sempurnanya transesterifikasi. Semakin tinggi persentase konversi, semakin sedikit jumlah trigliserida yang terdapat dalam biodiesel, sehingga semakin rendah densitas biodiesel yang dihasilkan. Data penelitian ini tidak dapat digunakan untuk membedakan keberadaan monogliserida, digliserida dan trigliserida yang dapat mempengaruhi densitas biodiesel. Keberadaan monogliserida dan digliserida sebagai hasil dari reaksi yang kurang sempurna sedikit/tidak mempengaruhi densitas, karena baik mono ataupun digliserida mempunyai densitas yang mirip dengan densitas biodiesel (Kac 2000).

Viskositas kinematik diperlukan untuk memperoleh viskositas bahan bakar yang sesuai dengan mesin yang digunakan. Pada viskositas diperlukan batasan minimum untuk menghindari hilangnya tenaga pompa dan kebocoran injektor dalam mesin, sedangkan batasan maksimum dalam kaitannya dengan desain dan ukuran mesin, serta karakter sistem injeksi (ASTM 2003 ${ }^{\text {a }}$. Titik nyala merupakan tendensi minyak untuk membentuk campuran yang mudah menyala dengan udara, hal ini mengindikasikan adanya bahan-bahan yang mempunyai volatilitas tinggi dan mudah terbakar. Selain itu juga berkaitan dengan keamanan dalam penanganan dan penyimpanan terhadap bahaya kebakaran (Yoeswono et al. 2007). Penetapan gliserol total digunakan untuk menetapkan kadar gliserol dalam bahan bakar. Kadar gliserol total yang tinggi dapat mengakibatkan deposit pada injektor, penyumbatan sistem bahan bakar, dan endapan pada tempat penyimpanan dan sistem bahan bakar. Berdasarkan data tersebut, maka biodiesel yang diperoleh telah memenuhi standar yang ditetapkan oleh ASTM.

\section{SIMPULAN}

Berdasarkan hasil penelitian dapat disimpulkan bahwa zeolit teraktivasi $\mathrm{HCl}$ dapat digunakan sebagai katalis dalam proses pra-transesterefikasi dalam pembuatan biodiesel. Kondisi optimal yang dicapai pada suhu $60^{\circ} \mathrm{C}$ dan konsentrasi zeolit alam aktif $2 \%$ memberikan konversi biodiesel tertinggi sebesar 100\%. Biodiesel yang dihasilkan dari minyak jelantah memenuhi kriteria dari ASTM $2003^{\text {b }}$ dan dirgen Migas 2006.

\section{UCAPAN TERIMA KASIH}

Penulis mengucapkan terimakasih kepada Universitas Jenderal Soedirman yang telah membiayai penelitian ini melalui DIPA UNSOED Tahun anggaran 2009, Dengan kontrak No. 1004.02/H23.6/PL/2009 tanggal 16 Maret 2009. Penulis juga mengucapkan terimakasih kepada Agus Dwi Harso dan Oki Isdiyanto yang telah membantu pengambilan sampel minyak jelantah.

\section{DAFTAR PUSTAKA}

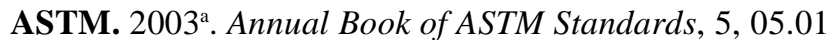
West Conshohocken: ASTM International.

ASTM. 2003 ${ }^{\mathrm{b}}$. Annual Book of ASTM Standards, 5, 05.04. West Conshohocken: ASTM International.

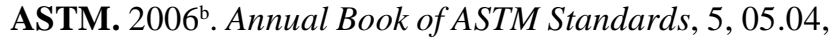
West Conshohocken: ASTM International.

BPStatistical Review of World Energy. 2010. Energy in 2009 from recession to recovery. bp.com/statisticalreview (20 Mei 2010).

Carmo Jr. A.C., De Souza, L.K.C., Da Costa, C.E.F., Longo, E., Zamian, J.R \& Da Rocha Filho, G.N. 2009. Production of biodiesel by esterification of palmitic acido over mesoporous aluminosilicate Al-MCM-41. Fuel 88(3): $461-468$

Chhetri, A.B., Watts, K.C \& Islam, M.R. 2008. Waste cooking oil as an alternate feedstock for biodiesel production. Energies 1: 3-18.

Chung K.H \& Park B.G. 2009. Esterification of oleic acid in soybean oil on zeolite catalysts with different acidity. J Ind Eng Chem 15: 388-392.

Dirjen Migas. 2006. Spesifikasi Bahan Bakar Minyak Jenis Solar 48, Nomor: 3675 K/24/DJM/2006. Jakarta: 17 Maret 2006.

Gerpen, J.V. 2005. Biodiesel processing and production. Fuel Process Technol 86: 1097-1107.

Heraldy, E., Hisyam, S.W \& Sulistyono. 2003. Karakterisasi dan aktivasi zeolit alam Ponorogo. Indo J Chem 3(2): 91-97.

Kac, A. 2000. The Two-Stage Adaptation of Mike Pelly's Biodiesel Recipe (For Advanced Biofuelers). http:// journeytoforever.org/ (14 November 2005).

Kartika, D. 2008. Hidrogenasi katalitik metil palmitat menjadi setil alkohol dengan katalis Ni/NZSiA. Tesis Pasca Sarjana. Yogyakarta: UGM.

Khairinal \& Trisunaryanti, W. 2000. Dealuminasi zeolit alam wonosari dengan perlakuan asam dan proses hidrotermal. Prosiding Seminar Nasional Kimia VIII. Universitas Gajah Mada,Yogyakarta. Yogyakarta: FMIPA-UGM. 
Khan, A.K. 2002. Research into Biodiesel, Kinetics \& Catalyst Development. Brisbane: Department of Chemical Engineering Queensland University.

Kiss, A.A., Dimian A.C \& Rothenberg, G. 2006. Solid acid catalysts for biodiesel production-towards sustainable energy. Adv Synth Catal 348: 75-81.

Knothe, G. 2000. Monitoring a progressing transesterification reaction by fiber-optic near infrared spectroscopy with correlation to ${ }^{1} \mathrm{H}$ Nuclear magnetic resonance spectroscopy. J Am Oil Chem Soc 77(9483): 489-493.

Knothe, G., Dunn, R.O \& Bagby, M.O. 1997. Biodiesel: The use of vegetable oils and their derivatives as alternative diesel fuels, fuels and chemicals from biomass. ACS Symposium Series, V, 666.

Lee, D.W., Park Y.M \& Lee, K.Y. 2009. Heterogeneous base catalysts for transesterification in biodiesel synthesis. Catal Surv Asia 13: 63-77.

Lou W.Y, Zong M.H \& Duan Z.Q. 2008. Efûcient production of biodiesel from high free fatty acid-containing waste oils using various carbohydrate-derived solid acid catalysts. Bioresource Technol 99: 8752-8758.

Pachenkov, G.M \& Lebedev, V.P. 1976. Chemical Kinetic and catalysis, ${ }^{\text {ed }}$ Ed. Moscow: Mir Publishers.

Pinto, A.C., Guarieiro, L.L.N., Rezende, M.J.C., Ribeiro, N.M., Torres, E.A., Lopes, W.A., de PPereira, P.A \& de Andrade, J.B. 2005. Biodiesel: An overview. Braz Chem Soc 16(6B): 1313-1330.
Rebeiro, F.R., Rodrigues, A.E., Rollman, L.D. \& Naccache, C. 1984. Zeolite Science and Technology. Denhaag: Martinus Nijhoff Publisher.

Salimon, J., Abdullah, B.M \& Salih, R012. Saponification of jatropha curcas seed oil: optimization by D-optimal design. Int J chem eng 2012: 574780.

Sharma Y.C., Singh, B \& Korstad, J. 2011. Advancements in solid acid catalysts for ecofriendly and economically viable synthesis of biodiesel, biofuels, bioprod. Bioref 5: 69-92.

Srivastava, A \& Prasad, R. 2000. Triglycerides-based diesel fuels. renew Sust Energ Rev 4(2): 111-133.

Trisunaryanti, W., Bambang, S \& Nazarudin. 2000. Determination of an Indonesian Natural Zeolite by Acids and Hydrothermal. Prosiding Seminar Nasional. Yogyakarta: FMIPA-UGM.

Yan, S., Salley, S.O \& Simon Ng. K.Y. 2009. Simultaneous transesterification and esterification of unrefined or waste oils over $\mathrm{ZnO}-\mathrm{La}_{2} \mathrm{O}_{3}$ catalysts. Appl Catal A-Gen 353: $203-212$.

Yoeswono, Triyono \& Tahir, I. 2007. The Use of Ash of Palm Empty Fruit Bunches as a Source of Base Catalyst for Synthesis of Biodiesel from Palm Kernel Oil. Proceeding of International Conferences on Chemical Sciences (ICCS-2007). Yogyakarta-Indonesia, 24-26 May 2007. 